\title{
Implication of public speaking anxiety on the employability of Omani graduates
}

\author{
Omer Ibrahim ${ }^{1}$ and Sonal Devesh ${ }^{1}$ \\ Corresponding author: Omer Ibrahim (omeribrahim@cbfs.edu.om) \\ ${ }^{1}$ College of Banking and Financial Studies, Oman
}

\begin{abstract}
The paper examines the implication of public speaking anxiety on the employability of Omani graduates. The study adopted a sequential, mixed research strategy, starting with in-depth interviews of teachers and managers in industry, followed by a structured questionnaire involving 200 students selected randomly from two colleges in Muscat. The statistical approach included exploratory factor analysis (EFA), and parametric tests. The study found that public speaking anxiety is widespread among students in higher education institutions in Oman, with a prevalence rate amounting to $55 \%$, much higher compared to the rates reported globally. The main factors involving public speaking anxiety in these education institutes in Oman were attributed to a lack of self-confidence, foreign language anxiety, being unprepared in, or fear of, talking in a foreign language, lack of experience, or forgetfulness/loss of memory. The implication of public speaking anxiety on employability of graduates in Oman is identified and some suggestions made based on the findings.
\end{abstract}

\author{
Keywords \\ public speaking \\ anxiety, \\ employability \\ skills, \\ exploratory \\ factor analysis, \\ Oman
}

\section{Introduction}

Employability skills have dramatically changed over the last two decades from original, or basic life skills and some knowledge to increasingly work-oriented concepts (Sung et al., 2013). Globalization and competition have greatly altered the way industry regards employment and the skills required for a job. Employability skills are perceived as a set of achievements - skills, understandings and personal attributes - that make graduates more likely to gain employment and be successful in their chosen occupations, which benefits them, the community and the economy (Yorke, 2006). These skills, which may be taught through education and workforce development systems, fall into three broad categories: applied knowledge, effective relationships and workplace skills.

Employability skills such as public speaking and effective communication have recently been considered pivotal for graduate recruitment (Campbell \& Larson, 2013; Dunbar, Brooks, \& KubickaMiller, 2006; Paadi, 2014; Polziehn, 2011; Selvadurai, Choy, \& Maros, 2012). According to Klaus, (2010), about $75 \%$ of long-term job success is attributed to people skills, and only $25 \%$ to technical knowledge. Moreover, soft skills including public speaking and business communication were rated the most important for entry-level success in employment (Wilhelm, 2004). These skills are required by students when they face interviews, presentations and public speaking occasions. They are also required in workplaces where employees are expected to communicate with the company's external 
partners and customers and internal employees, using video conferencing and panel discussions. Benefits of effective public speaking in the workplace include marketing the business and promoting products to a larger audience, producing a faster sales cycle, improving internal communication and increasing employee productivity, as well as establishing greater credibility and maintaining client loyalty (Nikitina, 2011).

Despite the importance of public speaking skills for graduate employability, studies have shown that many people, including students, experience great anxiety when contemplating public speaking (Çagatay, 2015; Dwyer \& Davidson, 2012; Goberman, Hughes, \& Haydock, 2011; Tse, 2012). For instance, Burnley, Cross and Spanos (1993) reported that approximately $85 \%$ of the general population showed some form of anxiety when delivering a speech. Eharman (1996) indicated that fear of public speaking is widespread among students, which may have a negative impact on their engagement with oral communication assessments and undermine their future career and employability.

McCroskey (1982) defined public speaking anxiety as a feeling of uneasiness or a state of fear, anticipating a threatening event, while Brown (1994) referred to it as a quality that causes people to be in a state of discomfort. The American Psychiatric Association (2013) considered it to be a fear of negative evaluation, which in the context of education is a measurable result that forms a part of the assessment process. Public speaking anxiety can negatively impact student employability and employee performance (Çagatay, 2015; Motley, 1997; Tse, 2012).

In Oman, the employment of graduates has become a challenge with the recent decline of oil prices and increasing numbers of graduates (NCSI, 2018). The Global Competitive Report has also confirmed that there is a lack of an educated workforce with employability skills, which constitutes the second most problematic factor impeding the ease of doing business in Oman (World Economic Forum, 2017). Graduates need to enhance their employability skills to compete effectively in the tight labour market.

Earlier research has shown that many Omani graduates leave their schools and/or colleges with limited communication skills, which impacts on their employability and future academic careers (AlMahrooqi \& Denman, 2016; Alamri, 2011; Carroll, Razvi, \& Goodliffe, 2009). Several reasons have been cited, including the limited qualifications of teachers, outdated teaching methods, lack of teacher motivation, and lack of a communicative-focused curriculum (Al-Mahrooqi, 2017). What is unknown is the level of anxiety among Omani students when delivering public speeches and how that impacts their employability. Also, the dynamic of causes needs to be explored to discover whether the limited communication skills relate only to English. Despite the prevalence and potential severity of the symptoms of public speaking anxiety among graduates in Oman, little research has been undertaken in this context.

The paper attempts to answer the following questions:

- What is the prevalent rate of public speaking anxiety in higher education in Oman?

- What are the main drivers of anxiety, and how do they impact graduates' employability?

Although in the workplace, interpersonal skills and communication are equally important, public speaking is just one element of oral communication skill development required by students to make them more employable. This paper focuses on public speaking anxiety and its influence on graduates' employability.

The findings are beneficial to the higher education policy makers in Oman as they offer insights into the major causes of anxiety experienced by students when speaking in public, and the strategies required to overcome such anxiety, thereby enhancing the employability skills of the graduates for better and effective engagement in the workplace.

Ibrahim, O., \& Devesh, S. (2019). Implication of public speaking anxiety on the employability of Omani graduates. Journal of Teaching and Learning for Graduate Employability, 10(2), 122-135. 


\section{Literature review}

Most people experience some level of anxiety when contemplating speaking in public, whether as students or employees. The rate of public speaking anxiety has been cited in the range of 20 to 30\%, or higher depending on the form of measurement used. A survey conducted by Chapman University in 2014 found that a fear of public speaking was the biggest phobia among respondents and $25.3 \%$ indicated a fear of speaking in front of a crowd. Of those who did present, nearly $70 \%$ agreed it was critical to their success at work (Ledbetter, 2014). Also, according to the national survey in the US, $21 \%$ of the respondents reported that they experienced a lifetime social fear of public speaking, which they considered to be on the extreme side, causing them considerable stress or avoidance (Ruscio et al., 2008). One study reported a prevalence rate of approximately $25 \%$ in a sample of a youth community who had a significant degree of fear of speaking in front of others (Knappe et al., 2011). Thirty four percent of a sample from Canada reported that they would be more nervous than others when speaking to a larger audience (Stein, Walker, \& Forde, 1996). However, in general, studies suggest that public speaking anxiety may affect up to $75 \%$ of people (McConnell, 2009; Motley, 1997; Tse, 2012).

In the higher education context, Beidel, Turner, Stanley and Dancu (1989) reported that, in a sample of undergraduates, $19 \%$ of the students were prone to a diagnosis of social phobia, whereas in a study conducted by Strahan (2003) on undergraduate males in an introductory psychology course, the findings indicated that $33 \%$ of the group suffered from social phobia symptoms. Studies conducted in UK universities by Russell and Shaw (2009) and in Sweden by Tillfors and Furmark, (2007) have documented clinically significant levels of social anxiety in 10 and $16 \%$ of students respectively.

This paper argues that public speaking anxiety is widespread among students in higher education institutes in Oman. Causes can be learner induced or foreign language related. This relates to the fact that in most public secondary schools, the medium of instruction is Arabic, and when students move to colleges, they have to learn through English instruction. Language anxiety is highly documented in the literature. The following literature supports this argument.

Çagatay (2015), studying Turkish students at the English preparatory program of the Turkish State University, showed that most of the students perceive speaking skills to be a major cause of anxiety. Cheng (2009) investigated the relationship between fear of public speaking and English-speaking proficiency among 300 students, selected from the Department of English at the Ming Chuan University. His results revealed that a lack of oratory skills, English proficiency, and weak knowledge of the topic being discussed, were among the most important factors triggering the fear of public speaking among the students surveyed. Occhipinti (2009) found that the majority of non-English speaking employees fear speaking in public, where lack of confidence, insecurity, and anxiety were among the main reasons contributing to their fear. The study added that a lack of experience in public speaking could extend to the college students because for most of them, their mother tongue was Arabic and they were required to convert to English, a foreign language. Al-Mahrooqi (2012) related the fear of speaking among Omani students to the fact that students themselves failed to see improvement in their English language proficiency; the lack of proficiency was the reason for anxiety when speaking. Moreover, despite the call for basic educational pedagogy in Oman to be learner-centred within a communicative-focused approach to teaching, more traditional teachercentred approaches still tend to dominate, contributing to the increase in students' fear of public speaking (Al-Mahrooqi, 2017). A student-centred approach is more likely to incorporate peer learning strategies and hence reduce anxiety.

Other strands of literature regard the causes of anxiety as learner induced or class related. According to Zhang and Zhong (2012), learner induced causes include: learners' unrealistic, erroneous or preconceived beliefs about language learning; setting of high, unrealistic standards; poor language skills; self-perception of poor ability and having a competitive nature, and fear of negative 
evaluation. Classroom induced anxiety causes include: level of perceived student support; manner of error correction; impact of complex speaking tasks, and instructors ignoring or exhibiting a lack of empathy for students' speaking anxiety. For Pertaub, Slater and Barker (2006) social anxiety was shown to be induced by the audience and the type of audience feedback the speaker received. A hostile or negative audience was found to generate more anxiety in speakers. Similarly, Wilson, (2006) reported that classroom activities and the learning/ teaching environment seem to have a direct bearing on students' anxiety and on their performance in speaking.

To address this anxiety, Çagatay (2015) recommended that students be provided with opportunities to speak in real-life situations, and that teachers create learning environments where the students can progress towards a stronger understanding and delivery of oral competence in front of their peers. A similar study conducted by Coleman (2005) considered that students be given the opportunity to feel more relaxed and confident while speaking English. Ward, Baruah and Jackson (2016) showed that use of a modified Public Speaking Competence Rubric (PSCR), developed by Schreiber, Paul and Shibley (2012) in assessment of a sequence of presentations, can rule out any predictable effect of assessor fatigue or gender bias.

Many studies have investigated the role of technology in addressing public speaking anxiety. Dupagne, Stacks and Giroux (2007) stated that students who observe their communication competency through self-directed technology can enhance their communication skills. By following a video recording of themselves, for example, students can monitor their performance or ask friends or peers for feedback. This can help reduce apprehension and improve their public speaking skills. Yalçın and İnceçay (2013) reported that practicing speaking spontaneously supports students in the process of overcoming their fear. Using games as spontaneous speaking activities can also play a significant role in decreasing speaking anxiety. Al-Mahrooqi (2012) demonstrated that adopting elearning techniques and joining English speaking clubs also can be effective ways to improve English proficiency. Only Campbell and Larson (2013) reported that there were no significant differences in the amount of anxiety, between delivering a traditional face-to-face speech and one using webconferencing technology. They suggested that public speaking skills are essential for presenting a clear understanding of the topic to the audience.

Public speaking anxiety has many implications for those experiencing it, whether as a student or in the workplace. Some studies show evidence that high rates of social anxiety result in more passive coping skills among students; reporting poor grades for tutorial participation, avoidance of units where oral presentations are required, or withdrawal from a degree and career pathway where public speaking is mandatory (Strahan, 2003). Other studies showed that individuals suffering from social phobia reported low work attendance, poor grades at school, lower education levels and lower overall pay (Schneier, et.al, 1992). In some severe cases, this form of anxiety can lead to a more extreme situation with complete social withdrawal (Goberman et al., 2011).

Given the above background, the purpose of this paper is to estimate the level of public speaking anxiety common among students in higher education in Oman and identify its main causes and how these impact graduates' employability. The research adopted a sequential mixed approach strategy to explore the extent of public speaking anxiety among students in higher education institutes in Oman, and its potential implication for employability.

\section{Methods}

The methodology of the study adopted was in-depth interviews followed by a questionnaire survey. The qualitative design was in the form of interviews with employers in the industry and teachers in public and private colleges in Muscat, to provide insight into the causes and implications of social anxiety on graduate employability. The quantitative design, on the other hand, adopted a structured questionnaire to measure the prevalence of public speaking anxiety among the student population of the colleges.

Ibrahim, O., \& Devesh, S. (2019). Implication of public speaking anxiety on the employability of Omani graduates. Journal of Teaching and Learning for Graduate Employability, 10(2), 122-135. 
Chronologically, the procedures for designing the survey questionnaire were conducted as follows:

1. A thorough literature review on public speaking anxiety and employability was conducted by the two authors. Following this, the authors developed an adapted survey questionnaire to suit the case study.

2. The questionnaire was then validated by two experts in the field, for construct and content validity.

3. The questionnaire was piloted with a sample of twenty respondents and demonstrated a high reliability of 0.804 based on Cronbach's Alpha.

4. As a result of the pilot test, three items were deleted to increase reliability, and the remaining twenty-nine items were considered for the final version of the questionnaire.

5. Four students were trained and assigned to collect the required data under the supervision of the second author of this study.

The sampling frame of the study was based on a stratified random sampling scheme to provide a better representation of the student population. The sample size for the survey was 200 students, selected from two colleges in Muscat. This sample size has been calculated with a precision of $5 \%$, margin of error of $6 \%$ and prevalence rate of graduate employability of $48 \%(\mathrm{MOH}, 2016)$. The target sample was originally 266 students; however, only 200 completed the questionnaire, providing a response rate of $75.2 \%$. This sample size would ensure that the survey results would provide good inference about the population, with $95 \%$ confidence. The recruitment of participants was based on a systematic selection from the list of students provided by the registration department of the respective colleges. The sampling interval was calculated by dividing the student population by the desired sample size in each college. The inclusive-exclusive criterion was based on nationality of students, involving Omani students only.

The study was conducted according to the principles stated in the declaration of the institute of the authors. The informed consent was collected from the students participating in the study. They were made aware in the consent form, that the results of the study would be published but that no data would be presented, to maintain anonymity of individuals. The project received ethical clearance from the authors' department of Postgraduate Studies and Research (Ref 1-2019).

In addition to the questionnaire, the study employed semi-structured interviews with nine Human Resources managers (working in government ministries and private sector) and three teachers from the two colleges. The interviews were conducted during the period Feb-March 2019. The interview time was about 25 minutes, on average.

For the statistical analysis, a parametric methods approach was used to estimate the prevalence of anxiety of public speaking and assess its implication on student employability. The relevant model in this respect is the one-sample t- test, where the mean prevalence of anxiety was compared to a benchmark of 2.5. This benchmark is the middle value in the Likert-type scale that was used to assess the existence of the anxiety based on the following research questions:

1. What is the prevalence of public speaking anxiety among Omani students?

2. What are the main drivers of anxiety, and how do they impact graduates' employability?

In addition, the researchers were interested in whether gender accounted for any difference in public speaking anxiety and the analysis of variance framework (ANOVA) was also used to determine whether there was a difference in public speaking anxiety related to level of study.

To investigate the pattern of public speaking anxiety among graduates in Oman, exploratory factor analysis (EFA) was used. The model was based on a principal-components analysis as the extraction technique, and Varimax as the orthogonal rotation method. The eigenvalue of greater than 1 , and

Ibrahim, O., \& Devesh, S. (2019). Implication of public speaking anxiety on the employability of Omani graduates. Journal of Teaching and Learning for Graduate Employability, 10(2), 122-135. 
the cross loadings of at least 0.5 criteria were used, as suggested by Hair et al.(2010). The computer software of SPSS version 24 was used in the analysis of the data.

\section{Results}

A descriptive analysis was conducted to describe the characteristics of the students selected in the sample, in terms of gender and level of study at the colleges.

Table 1: Demographic Profile of the Sample Data $(n=200)$

\begin{tabular}{llll}
\hline $\begin{array}{l}\text { Demographic } \\
\text { Variables }\end{array}$ & Categories & $\mathbf{N}$ & $\%$ \\
\hline Gender & Male & 62 & 31 \\
& Female & 138 & 69 \\
\hline Length of time at & One year & 100 & 50 \\
college & Two years & 60 & 30 \\
& Three Years & 40 & 20 \\
\hline
\end{tabular}

Source: Authors' calculation

As Table 1 indicates, most of the respondents (69\%) were female and 50\% were first year students. Year level was introduced as a proxy to assess the effectiveness of the communicative-focused curriculum adopted by these colleges to reduce the anxiety of speaking in public.

\section{Exploratory factor analysis}

An exploratory factor analysis was conducted to identify the factors influencing the anxiety of public speaking in higher education institutes in Oman. Keiser-Meyer-Olkin measure (KMO) measure of sampling adequacy and Bartlett's test of sphericity were found to be 0.930 and 0.000 respectively, as shown in Table 2 . These results indicate a high sampling adequacy and justify proceeding with factor analysis.

Table 2: KMO and Bartlett's tests

Kaiser-Meyer-Olkin measure of sampling adequacy

Bartlett's test of sphericity

0.930

Approx. Chi -square $\quad 3810.1$

Degree of freedom $\quad 325$

Significance $\quad 0.000$

Source: Authors' calculation

Factor analysis, as shown in Table 3, led to seven factors, which account for $72.38 \%$ of the cumulative variance, which is acceptable in a multivariate analysis technique such as factor analysis.

Table 3: Factor Analysis for Public Speaking Anxiety

\begin{tabular}{ccccccc}
\hline Items & \multicolumn{2}{c}{ Initial Eigen values } & \multicolumn{4}{c}{ Extraction Sum of squared loadings } \\
\hline & Total & $\begin{array}{c}\text { \% of } \\
\text { Variance }\end{array}$ & $\begin{array}{c}\text { Cumulative } \\
\text { \% }\end{array}$ & Total & $\begin{array}{l}\text { \% of } \\
\text { Variance }\end{array}$ & Cumulative \% \\
\hline $\mathbf{1}$ & 11.5 & 39.8 & 39.8 & 11.5 & 39.8 & 39.8 \\
\hline $\mathbf{2}$ & 2.4 & 8.4 & 48.2 & 2.4 & 8.4 & 48.2 \\
\hline $\mathbf{3}$ & 1.7 & 6.0 & 54.2 & 1.7 & 6.0 & 54.2 \\
\hline $\mathbf{4}$ & 1.7 & 5.8 & 60.0 & 1.7 & 5.8 & 60.0 \\
\hline $\mathbf{5}$ & 1.3 & 4.6 & 64.6 & 1.3 & 4.6 & 64.6 \\
\hline
\end{tabular}

Ibrahim, O., \& Devesh, S. (2019). Implication of public speaking anxiety on the employability of Omani graduates. Journal of Teaching and Learning for Graduate Employability, 10(2), 122-135. 


\begin{tabular}{ccccccc}
\hline $\mathbf{6}$ & 1.2 & 4.2 & 68.7 & 1.2 & 4.2 & 68.7 \\
\hline $\mathbf{7}$ & 1.1 & 3.7 & 72.4 & 1.1 & 3.7 & \\
\hline $\mathbf{8}$ & 0.8 & 2.8 & 75.1 & & & \\
\hline $\mathbf{9}$ & 0.8 & 2.6 & 77.8 & & \\
\hline $\mathbf{1 0}$ & 0.7 & 2.4 & 80.1 & & \\
\hline $\mathbf{1 1}$ & 0.7 & 2.3 & 82.4 & & \\
\hline $\mathbf{1 2}$ & 0.6 & 2.1 & 84.5 & & \\
\hline $\mathbf{1 3}$ & 0.5 & 1.8 & 86.3 & & \\
\hline $\mathbf{1 4}$ & 0.5 & 1.6 & 87.9 & & \\
\hline $\mathbf{1 5}$ & 0.5 & 1.6 & 89.5 & & \\
\hline $\mathbf{1 6}$ & 0.4 & 1.4 & 90.9 & & \\
\hline $\mathbf{1 7}$ & 0.4 & 1.2 & 92.1 & & \\
\hline $\mathbf{1 8}$ & 0.3 & 1.1 & 93.3 & & \\
\hline $\mathbf{1 9}$ & 0.3 & 1.0 & 94.3 & & \\
\hline $\mathbf{2 0}$ & 0.3 & 0.9 & 95.2 & & \\
\hline $\mathbf{2 1}$ & 0.2 & 0.9 & 96.1 & & \\
\hline $\mathbf{2 2}$ & 0.2 & 0.7 & 96.8 & & \\
\hline $\mathbf{2 3}$ & 0.2 & 0.7 & 97.5 & & \\
\hline $\mathbf{2 4}$ & 0.2 & 0.6 & 98.1 & & \\
\hline $\mathbf{2 5}$ & 0.2 & 0.6 & 98.7 & & \\
\hline $\mathbf{2 6}$ & 0.1 & 0.4 & 99.1 & & \\
\hline $\mathbf{2 7}$ & 0.1 & 0.3 & 99.4 & & \\
\hline $\mathbf{2 8}$ & 0.1 & 0.3 & 99.7 & & \\
\hline $\mathbf{2 9}$ & 0.1 & 0.3 & 100.0 & & \\
\hline
\end{tabular}

Source: Authors' calculation

The interpretations of the seven factors are shown in Table 4. The first factor, referred to as 'symptoms of anxiety', consists of items 14, 24, 27, 32, 36 and 38. This factor explains $39.79 \%$ of the total variance. The second factor, referred to as 'self-confidence', contains items 9,11 and 13, and accounts for $8.3 \%$ of total variance. The third factor, 'foreign language anxiety', consists of items 16 , 17, 25, 29 and 31, and accounts for $6 \%$.

The fourth factor, 'preparedness for presentation', consists of items 28 and 30 , accounting for $5.78 \%$ of total variance. The fifth factor, 'fear of foreign language speech', consists of items 8, 10 and 23, accounting for $4.6 \%$ of total variance. The sixth factor, referred to as 'experience' consists of item 37 , accounting for $4.51 \%$ of total variance. The seventh factor, 'memory loss /forgetfulness' consists of items 18 and 34 , accounting for $3.67 \%$ of the total variance.

\section{Table 4: Speaking Anxiety Factors}

\begin{tabular}{llcc}
\hline $\begin{array}{l}\text { Item } \\
\text { No. } \\
\text { Overall alpha }\end{array}$ & $\begin{array}{c}\text { Initial } \\
\text { Communalities }\end{array}$ & \begin{tabular}{c} 
Extraction \\
\multicolumn{1}{c}{ Symptoms of Anxiety }
\end{tabular} & $\begin{array}{c}\text { Cronbach's } \\
\text { alpha } \\
0.804\end{array}$ \\
\hline Q14 & $\begin{array}{l}\text { When the instructor announces an English } \\
\text { speaking assignment, I can feel myself getting } \\
\text { tense. }\end{array}$ & 1.000 & .673 \\
Q24 & $\begin{array}{l}\text { My heart beats very fast just as I start to speak. } \\
\text { Realizing that only a little time remains in a } \\
\text { presentation makes me very tense and anxious. } \\
\text { I feel anxious when the teacher announces the } \\
\text { date of an English speaking assignment. }\end{array}$ & 1.000 & .599 \\
Q32 & 1.000 & .571 & .668 \\
\end{tabular}




\begin{tabular}{|c|c|c|c|}
\hline Q36 & $\begin{array}{l}\text { My heart beats very fast while I am giving a } \\
\text { presentation in English }\end{array}$ & 1.000 & .667 \\
\hline Q38 & $\begin{array}{l}\text { While giving a presentation in English I get so } \\
\text { nervous I forget facts I really know }\end{array}$ & 1.000 & .756 \\
\hline \multicolumn{4}{|c|}{$\begin{array}{l}\text { Self Confidence } \\
\end{array}$} \\
\hline Q9 & $\begin{array}{l}\text { Right after giving a speech in English I feel that I } \\
\text { have had a pleasant experience }\end{array}$ & 1.000 & .582 \\
\hline Q11 & I am not afraid of giving a speech in English. & 1.000 & .686 \\
\hline Q13 & I look forward to giving a speech in English. & 1.000 & .576 \\
\hline \multicolumn{4}{|c|}{$\begin{array}{l}\text { Foreign Language Anxiety } \\
\end{array}$} \\
\hline Q16 & I feel relaxed while giving a speech in English & 1.000 & .630 \\
\hline Q17 & I enjoy preparing for a speech in English. & 1.000 & .588 \\
\hline Q25 & $\begin{array}{l}\text { I experience considerable anxiety just before } \\
\text { my presentation starts. }\end{array}$ & 1.000 & .625 \\
\hline \multirow[t]{2}{*}{ Q27 } & Realizing that only a little time remains in an & & \\
\hline & $\begin{array}{l}\text { English presentation makes me very tense and } \\
\text { anxious. }\end{array}$ & 1.000 & .571 \\
\hline Q29 & $\begin{array}{l}\text { I breathe faster just before starting a } \\
\text { presentation in English }\end{array}$ & 1.000 & .591 \\
\hline Q31 & $\begin{array}{l}\text { I perform less well in oral presentations } \\
\text { because I am anxious. }\end{array}$ & 1.000 & .641 \\
\hline \multicolumn{4}{|c|}{ Readiness/Preparedness for Language Speech } \\
\hline Q28 & $\begin{array}{l}\text { While giving an English speech, I know I can } \\
\text { control my feelings of tension and stress. }\end{array}$ & 1.000 & .711 \\
\hline Q30 & $\begin{array}{l}\text { I feel comfortable and relaxed in the hour or so } \\
\text { just before giving an English speech }\end{array}$ & 1.000 & .598 \\
\hline \multicolumn{4}{|c|}{ Fear of Foreign Language Speech } \\
\hline Q8 & $\begin{array}{l}\text { My thoughts become confused and jumbled } \\
\text { when I am giving a speech in English. }\end{array}$ & 1.000 & .733 \\
\hline Q10 & $\begin{array}{l}\text { I get anxious when I think about a presentation } \\
\text { in English coming up. }\end{array}$ & 1.000 & .731 \\
\hline Q23 & $\begin{array}{l}\text { I perspire just before starting a speech in } \\
\text { English. }\end{array}$ & 1.000 & .545 \\
\hline \multicolumn{4}{|c|}{ Experience } \\
\hline Q37 & $\begin{array}{l}\text { I feel anxious while waiting to give my speech in } \\
\text { English }\end{array}$ & 1.000 & .552 \\
\hline \multicolumn{4}{|c|}{ Loss of Memory/Forgetfulness } \\
\hline Q18 & $\begin{array}{l}\text { I am in constant fear of forgetting what I } \\
\text { prepared to say when speaking in English. }\end{array}$ & 1.000 & .593 \\
\hline Q34 & $\begin{array}{l}\text { During an important speech in English, I } \\
\text { experience a feeling of helplessness building up } \\
\text { inside me }\end{array}$ & 1.000 & .626 \\
\hline
\end{tabular}

Source: Authors' calculation

To test the level of anxiety of public speaking among students in higher education institutes in Oman, a one-sample test was used, and the result is given in Table 5.

Table 5: The average level of anxiety among students in the sample

\begin{tabular}{|c|c|c|c|c|c|}
\hline Mean & Test value & T- value & P-value & Df & $\begin{array}{l}95 \% \text { Confidence interval } \\
\text { of the mean difference }\end{array}$ \\
\hline
\end{tabular}

Ibrahim, O., \& Devesh, S. (2019). Implication of public speaking anxiety on the employability of Omani graduates. Journal of Teaching and Learning for Graduate Employability, 10(2), 122-135. 


\begin{tabular}{lcccccc}
\hline & & & & Lower & Upper \\
\hline $\mathbf{3 . 0 5 4}$ & 2.50 & 14.637 & 0.000 & 199 & 0.4802 & 0.6298 \\
\hline Source: & Authors' calculation & & & &
\end{tabular}

Source: Authors' calculation

As can be seen from Table 5, the average level of anxiety about public speaking experienced by the students amounted to 3.05, which is significantly higher than the cut-off of 2.5 (p-value of the test $0.000<0.05$ ). In fact, $55 \%$ in the sample indicated this high level of anxiety when speaking in public.

Table 6: The Average Anxiety of Public Speaking by Gender

\begin{tabular}{l|c|c|c|c}
\hline Gender & Average & Standard Deviation & T-value & P-value \\
\cline { 1 - 3 } Male & 3.03 & 0.54 & -1.563 & \multirow{2}{*}{0.128} \\
\cline { 1 - 3 } Female & 3.21 & 0.52 & & \\
\hline
\end{tabular}

Source: Authors' calculation

Table 6 shows the average level of anxiety about public speaking as experienced by male and female students in the sample. Results revealed that there is no significant difference in average anxiety between male and female students ( $P$-value $>0.05$ ).

Table 7: The Average Anxiety of Public Speaking by Level of Study

\begin{tabular}{l|r|c|c|c|c}
\hline Level of study & \multicolumn{1}{|c|}{ N } & Average & Standard Deviation & F-value & P-value \\
\hline First year & 100 & 3.41 & .37 & & \\
\cline { 1 - 4 } Second year & 60 & 2.69 & .41 & \multirow{2}{*}{75.95} & \multirow{2}{*}{.000} \\
\cline { 1 - 4 } Third year & 40 & 2.72 & .48 & & \\
\cline { 1 - 4 } Total & 200 & 3.05 & .54 & & \\
\hline
\end{tabular}

Source: Authors' calculation

The results of the ANOVA in Table 7 indicated a significant difference in average public speaking anxiety across the levels of study. The average level of anxiety declines as students' language proficiency increases. This might be attributed to the fact that as students progress, they will be exposed to many oral-focused courses, resulting in a decrease of anxiety about public speaking.

\section{Discussion and implication}

When addressing the first research question about the prevalent rate of public speaking anxiety in higher education in Oman, the study found that this amounts to $55 \%$. This rate is relatively higher than the average rate of $20 \%$ reported globally in some higher education contexts (Beidel et al., 1989; Russel \& Shaw, 2009 ; Tillfors \& Furmark, 2007). It is also higher than the rates shown in the general public, identified by Knappe et al. (2011). The study indicated no significant difference in anxiety rates between male and female students, which is consistent with many studies, including those by Aida (1994), Campbell (1999), Mathew et al. (2013), and Matsuda \& Gobel (2004). However, this is inconsistent with studies by Fariadian, Azizifar and Gowhary (2014), Eleldi (2016) and Gargalianou (2015), who reported that male students have a higher level of foreign language anxiety than female students and other studies which revealed that females feel more anxious than males (Torres, 2006 ; Pappamihiel, 2001; Piechurska-kuciel, 2012). It may be that in Oman, cultural factors may be responsible for males and females being exposed to some level of anxiety. Khan and Al-Mahrooqi (2015) demonstrated that Omani higher education students are well known for being polite, considerate and respectful to their teachers, and hence they care about sustaining this image in front of their teachers.

For the second research question, relating to the factors influencing anxiety in higher education in Oman, results indicated that several elements, such as self-confidence are contributing factors 
confirming the findings of Crookall and Oxford (1991), Alharbi (2015), Al-Mahrooqi (2012), Çagatay (2015), Cheng (2009), and Coleman, (2005). Foreign language anxiety and fear of speaking in public in a foreign language, are other identified factors. Many Omani students lack confidence when speaking in English, which may affect them negatively as confirmed by Al-Mahrooqi and Denman (2016), Alamri (2011), Tanveer (2007), and Young (1990). The lack of readiness/preparedness creates anxiety, as demonstrated by Al-Mahrooqi (2017). Temporary memory loss or forgetfulness has been found to influence anxiety of students when about to speak in public. This factor is consistent with Horwitz and Cope (1986) who reported that some students faced a 'mental block' during speaking in front of others.

The study also found that the average level of anxiety declines as students progress in their language skills. The same result was confirmed by Dalkilic (2001) and Liu (2006) who demonstrated that public speaking anxiety declines with students' progress towards higher levels of proficiency.

The implications of public speaking anxiety on student employability in Oman emerged during interviews with teachers and managers in industry and included the inability of students to demonstrate their skills well and a lack of self-confidence, resulting in low overall performance. These results are consistent with the findings of Schneier et al. (1992). Interviews with managers emphasized the importance of interpersonal skills (such as leadership and teamwork), including public speaking, which is necessary for the training they conduct, video conferencing and panel discussions when communicating with staff and customers. Managers working in the public sector, in particular, added that graduates experience anxiety even when using Arabic, their mother tongue. This is an unexpected finding worth exploring in the future. Moreover, the teachers interviewed suggested that anxiety about public speaking sometimes influences students' choice of specialization after they graduate. They may choose a profession that requires less public speaking, even though it is not their choice of specialization. This confirms the opinion of Strahan (2003).

When dealing with the problem of public speaking anxiety, students demonstrated different coping strategies that need to be considered when establishing initiatives to mitigate the effects of their anxiety. These include coaching, laughing, taking a walk to relax, seeking direction and training to improve public speaking skills, paying attention to the physical signs of stress during speaking, and writing their experiences in a learning logbook so that they can reflect on how they felt and consider how to improve. The teachers emphasised that public speaking should be a highly rated component of the curriculum as it is one of the most useful soft skills required for employability. They recommended increasing the number of public speaking courses in the curriculum, inviting guest lecturers who specialize in public speaking to motivate and encourage group discussions, peer conversations, and paying attention to group dynamics among students. They also highlighted the importance of encouraging students to note their experiences of public speaking anxiety in a learning logbook, work on areas of weakness and strength, and monitor their progress. The use of visualization techniques has also proved to be effective in enhancing public speaking performance, as well as reducing anxiety (Ayres \& Hopf, 2009).

To promote student employability, managers recommended providing more training to develop students' confidence in their ability to stand up in public and talk to a group of people. Training that simply provides information about 'how to present' may be insufficient, whereas models that borrow from psychological interventions which address social anxiety and fear of negative evaluation would be useful (England et al., 2012). They also called for the development of other interpersonal skills (such as leadership and teamwork) as public speaking is just one element of the broader set of oral communication skills required by students to make them more employable. Moreover, interviews with teachers and managers revealed that public speaking anxiety in Oman should be addressed at earlier stages of education, at primary or secondary levels, so that by the time students reach college they are confident to speak in public, both in Arabic and English and can use these skills later to become effective in their workplace.

Ibrahim, O., \& Devesh, S. (2019). Implication of public speaking anxiety on the employability of Omani graduates. Journal of Teaching and Learning for Graduate Employability, 10(2), 122-135. 


\section{Limitations and future research}

One limitation of this study is its small size and focus on colleges in the capital (Muscat) only. Despite this, there are some interesting findings worthy of further investigation in an expanded study to include all higher education institutions in Oman. It would also be worthwhile exploring why students feel anxious when speaking in public in their own language. Other soft skills, such as interpersonal skills, are important and need to be explored in future research regarding student's employability in Oman.

\section{Conclusion}

Public speaking anxiety is widespread among students in higher education institutions in Oman. Its prevalence rate was 55\%, much higher than reported internationally. Public speaking anxiety has major implications for student performance, career choice and employability, and higher education institutions in Oman must address this concern as a priority. They should enhance interpersonal skills, including public speaking, among students through professional development of teachers, incorporating an updated communicative-focused curriculum. This can be achieved by conducting training sessions for higher secondary and tertiary educators, promoting oratory skills in the curriculum, and developing appropriate assessment techniques. This will further provide students with effective strategies that reduce their anxiety and promote their communication skills.

When designing the curriculum educators should consider feedback obtained from employers, as this can further improve the standard of education, resulting in fulfilment of the needs of students and society. Promoting public speaking skills at the earlier stages of education in Oman is essential, to reduce the need to address this at tertiary levels. In the workplace, managers must identify related problems early and provide their employees with the required training, as well as communicate with the education institutions regarding the skills required in the labour market.

\section{References}

Aida, Y. (1994). Examination of Horwitz, Horwitz and Cope's construct of foreign language anxiety: The case of students of Japanese. The Modern Language Journal, 78(2), 155-167.

Alharbi, H.A. (2015). Improving students' English speaking proficiency in Saudi public schools. International Journal of Instruction, 8(1), 1308-1470.

Alamri, M. (2011). Higher education in Saudi Arabia. Journal of Higher Education Theory and Practice, 11(4), 88-91.

Al-Mahrooqi, R. (2017). Omani public school supervisor evaluations of English communication in EFL classrooms. A paper presented at the conference Pedagogia 2017. Retrieved from: https://www.researchgate.net/publication/313367554_Omani_public_school_supervisor_evaluation S_of_English_communication_in_EFL_classrooms

Al-Mahrooqi, R., \& Denman C. (2016). Establishing a reading culture in Arabic and English in Oman. Arab World English Journal, 7(1), 5-17.

Al-Mahrooqi, R. (2012). English communication skills: How are they taught at schools and universities in Oman? English Language Teaching, 5(4), 124-130.

American Psychiatric Association, $5^{\text {th }}$ Ed. (2013). Diagnostic and statistical manual of mental disorders. American Psychiatric Association.

Ayres, J., \& Hopf, T. S. (2009). Visualization: A means of reducing speech anxiety. Communication Education, 34(4), 318-323.

Beidel, D., Turner, S., Stanley, M., \& Dancu, C. (1989). The social phobia and anxiety inventory: Concurrent and external validity. Behavior Therapy, 20(3), 417-427.

Brown, H. D. (1994). Principles of language learning and teaching, (3 $3^{\text {rd }}$ Ed.). NJ: Prentice Hall.

Burnley, M., Cross, P., \& Spanos, N. (1993). The effects of stress inoculation training and skills training on the treatment of speech anxiety. Imagination, Cognition and Personality, 12(1), 355-366.

Ibrahim, O., \& Devesh, S. (2019). Implication of public speaking anxiety on the employability of Omani graduates. Journal of Teaching and Learning for Graduate Employability, 10(2), 122-135. 
Çagatay, S. (2015). Examining EFL students' foreign language speaking anxiety: The case at a Turkish state university. Procedia - Social and Behavioral Sciences, 199(6), 648-656.

Campbell S., \& Larson J. (2013). Public speaking anxiety: Comparing face to face and web based speeches. Journal of Instructional Pedagogies, 1, 1-8.

Campbell, C. (1999). Language anxiety in men and women: Dealing with gender differences in the language classroom. In D. Young, Affect in foreign language and second language learning: $A$ practical guide to creating a low anxiety classroom atmosphere, (pp. 191- 205). Boston: McGraw- Hill.

Carroll, M., Razvi, S., \& Goodliffe, T. (2009). Using foundation program academic standards as a quality enhancement tool. A paper for INQAAHE 2009. Retrieved from: https://www.researchgate.net/publication/237725311.

Cheng, L. (2009). Language anxiety and English speaking proficiency. CA: Sage Publications.

Coleman, L.E. (2005). Drama-based English and foreign language instruction for Korean adolescents. Dissertation Abstracts International 66 (UMI 3184346). Retrieved from: https://www.researchgate.net/publication/261995985_Drama_in_Oman_to_improve_English_profic iency_among_English_major_college_students

Crookall, D., \& Oxford, R. L. (1991). Dealing with anxiety: Some practical activities for language learner and teacher trainees. In E.K. Horwitz \& D.J. Young (Eds.), Language: From theory and research to classroom implications (pp. 141-50). Englewood Cliffs, NJ: Prentice Hall.

Dalkilic, N. (2001). An investigation into the role of anxiety on students' success in second language learning. Unpublished doctoral dissertation, Cukurova University.

Zhiping, D., \& Paramasivam, S. (2013). Anxiety of speaking English in class among international students in a Malaysian University. International Journal of Education and Research, 1(11), 1-16.

Dunbar, N.E., Brooks, C.F., \& Kubicka-Miller, T. (2006). Oral communication skills in higher education: Using a performance-based evaluation rubric to assess communication skills. Innovative Higher Education, 31(2)115-128.

Dupagne, M., Stacks, D. W., \& Giroux, V. M. (2006). Effects of video streaming technology on public speaking students, communication apprehension and competence. Journal of Educational Technology Systems, 35(4), 479-490.

Dwer, K., \& Davidson, M. (2012). Is public speaking really more feared than death? Research Reports, 20(2), 99-107.

Eharman, M. (1996). Understanding second language learning difficulties. London: Sage Publications INC.

Eleldi, S. (2016). Foreign language anxiety of students studying English language and literature: A sample from Turkey. Academic Journals, 11(6), 219-228.

England, E.L., Herbert, J.D., Forman, E.M., Rabin, S.J., Juarascio, A., \& Goldstein, S.P. (2012) Acceptancebased exposure therapy for public speaking anxiety. Journal of Contextual Behavioral Science, 1(1), 66-72.

Fariadian, E., Azizifar, A., \& Gowhary, H. (2014). The effect of anxiety on Iranian EFL learners speaking skill. International Research Journal of Applied and Basic Sciences, 8(10), 1747-1754.

Gargalianou, V. (2015). The effects of gender and personality on foreign language anxiety among adult multilingual. Belgium: University of Antwerp, SCHUMPETER School of Business and Economics.

Goberman, A.M., Hughes, S., \& Haydock, T. (2011). Acoustic characteristics of public speaking: Anxiety and practice effects. Speech Communication, 53(6), 867-876.

Hair, J.F., Black, W.C., Babin, B.J., \& Anderson, R.E. (2010). Multivariate data analysis. Seventh Edition. Prentice Hall, Upper Saddle River, New Jersey

Horwitz, E. K., Horwitz, M. B., \& Cope, J. A. (1986). Foreign language classroom anxiety. The Modern Language Journal, 70(2), 125-132. http://dx.doi.org/10.2307/327317

Khan, A., Al-Mahrooqi, R. (2015). Foreign language communication anxiety (FLCA) among tertiary level Omani EFL learners. The Asian AFL Journal, 17(1), 57-85.

Klaus, P. (2010). Communication breakdown. California Job Journal, 28(1), 1-9.

Knappe, S., Beesdo-Baum, K., Fehm, L., Stein, M.B., Lieb, R. \& Wittchen, H.U. (2011). Social fear and social phobia types among community youth: Differential clinical features and vulnerability factors. Journal of Psychiatric Research, 45, 111-120.

Ibrahim, O., \& Devesh, S. (2019). Implication of public speaking anxiety on the employability of Omani graduates. Journal of Teaching and Learning for Graduate Employability, 10(2), 122-135. 
Ledbetter, S. (2014). What Americans fear most - New poll from Chapman University. Retrieved from: https://blogs.chapman.edu/press-room/2014/10/20/what-americans-fear-most-new-poll-fromchapman-university/

Liu, M. (2006). Anxiety in Chinese EFL students at different proficiency levels. System, 34(3), 301-316.

Mathew, P., Mundakkal, L. Job, Al Damen, T., \& Mohammad, R.I. (2013). An Arab EFL context: Does variance in anxiety and motivation across gender impact language attainment? Studies in Literature and Language, 6(3), 14-22.

Matsuda, S., \& Gobel, P. (2004). Anxiety and predictors of performance in the foreign language classroom. System, 32(1), 21-36.

McConnell, C.R. (2009) .Effective oral presentations: Speaking before groups as part of your job. The Health Care Manager, 8(3), 264-272.

McCroskey, J. C. (1982). Oral communication apprehensive: A reconceptualization, In Michael Burgoon (Ed.), Communication yearbook, 6(1) (pp.271- 294). CA: Sage Publications.

Ministry of Higher Education (MOH) (2016). Higher education survey: Only 48\% of new graduates are employed. Retrieved from: http://www.ogss.gov.om/en/media-center/news/113-2222-2

Motley, M.T. (1997). Overcoming your fear of public speaking: A proven method. University of California, CA: Davis Houghton Mifflin Company.

National Center for Statistics and Information (2018). Statistical Yearbook issue 46-2018. Oman. National Center for Statistics and Information.

Nikitina, A. (2013). Successful public speaking. Academic Transfer. Retrieved from https://www.isbtweb.org/fileadmin/user_upload/successful-public-speaking.pdf

Occhipinti, L. (2009). Foreign language anxiety in in-class speaking activities. Journal of Communications, 11(3), 1-112.

Paadi, K. (2014). Perceptions on employability skills necessary to enhance human resource management graduates prospects of securing a relevant place in the labour mark. European Scientific Journal, Special Edition, 129-143.

Pappamihiel, N.E. (2001). Moving from the ESL classroom into the mainstream: An investigation of English language anxiety in Mexican girls. Bilingual Research Journal, 25(1-2), 31-38.

Pertaub, D. P., Slater, M., \& Barker, C. (2006). An experiment on fear of public speaking in virtual reality. Cyberpsychology \& Behaviour, 9(5), 627-33.

Piechurska-Kuciel, E. (2012). Gender-dependent language anxiety in Polish communication apprehensive. Studies in Second Language Learning and Teaching, 2 (2), 227-248.

Polziehn, R. (2011) .Skills expected from graduate students in search of employment in academic and nonacademic settings. Retrieved from: https://d1pbog36rugm0t.cloudfront.net//media/gradstudies/migrated-media/prof dev/career/careerskillsexpected.pdf

Ruscio, A.M., Brown, T.A., Chiu, W.T., Sareen, J., Stein, M.B., \& Kessler, R.C. (2008). Social fears and social phobia in the USA: Results from the national comorbidity survey replication. Psychological Medicine, $38(1), 5-28$.

Russell, G., \& Shaw, S. (2009). A study to investigate the prevalence of social anxiety in a sample of higher education students in the UK. Journal of Mental Health, 18(3), 198-206.

Schneier, F.R., Johnson, J., Hornig, C.S., Liebowitz, M.R., \& Weissman, M.M. (1992). Social phobia. Comorbidity and morbidity in an epidemiologic sample. Archives of General Psychiatry, 49(4), 282288.

Schreiber, L.M., Paul, G.D., \& Shibley, L. R. (2012). The development and test of the public speaking competence rubric. Communication Education, 61(3), 205-233.

Selvadurai, S., Choy, E.A., \& Maros, M. (2012). Generic skills for prospective graduates from employers' perspectives. Asian Social Studies, 8(12), 295-303.

Stein, M.B., Walker, J.R., \& Forde, D.R. (1996) .Public speaking fears in a community sample: Prevalence, impact on functioning, and diagnostic classification. Archives of General Psychiatry, 53(2), 169-174.

Strahan, E. (2003). The effects of social anxiety and social skills on academic performance. Personality and Individual Differences, 34(2), 347-366.

Sung J., Michael, C., Loke, F., \& Ramos, C. (2013). The nature of employability skills: Empirical evidence from Singapore. Special Issue on Employability Skills, International Journal of Training and Development, 17(3), 176-193.

Ibrahim, O., \& Devesh, S. (2019). Implication of public speaking anxiety on the employability of Omani graduates. Journal of Teaching and Learning for Graduate Employability, 10(2), 122-135. 
Tillfors, M., \& Furmark, T. (2007). Social phobia in Swedish university students. Social Psychiatry and Psychiatric Epidemiology, 42(1), 79-86.

Tanveer, M. (2007). Investigations of the factors that cause language anxiety for ESL/EFL learners in learning speaking skills and the influence it casts on communication in the target language. Unpublished master's thesis, University of Glasgow, Scotland

Torres, R.L. (2006). Gender and anxiety among international high school second language learners. Journal of Border Educational Research, 5, 6-13.

Tse, A.Y.H. (2012). Gloss phobia of university students in Malaysia. International Journal of Asian Social Science, 2(11), 2061-2073.

Ward, T., Baruah, B. J., \& Jackson, N. (2016). The assessment of engineering student public speaking ability: What, how and issues. International Conference on Engineering Education and Research, Sydney, Australia, Nov. 2016, p. 8.

Wilhelm, W. J. (2004). Determinants of moral reasoning: Academic factors, gender, richness of life experiences, and religious preferences. Delta Pi Epsilon Journal, 46(2), 105-121.

Wilson, J.T.S. (2006). Anxiety in learning English as a foreign language; its associations with students' variables, with overall proficiency, and with performance in an oral test. PhD Thesis, LA Director, Universidad De Granada.

World Economic Forum (2017). The global competitiveness report 2015-2016. Retrieved from: http://reports.weforum.org/global-competitiveness-report-2015-2016/results-overview.

Yalçın, O.A., \& Inceçay, V. (2013). Foreign language speaking anxiety: The case of spontaneous speaking activities. 5th World Conference on Educational Sciences - WCES 2013 Procedia - Social and Behavioural Sciences, 116 (2014), 2620-2624. Retrieved from: www.sciencedirect.com.

Yorke, M. (2006). Employability in higher education: What it is - what it is not? Learning and employability. Series 1. York: The Higher Education Academy. Retrieved from: http://www.heacademy.ac.uk/assets/documents/tla/employability/id116_employability_ in_higher_education_336.pdf.

Young, D. J. (1990). An investigation of students' perspectives on anxiety and speaking. Foreign Language Annals, 23(6), 539-553.

Zhang, R., \& Zhong, J. (2012). The hindrance of doubt: Cause of language anxiety. International Journal of English Linguistics, 2(3), 27-33 